International Journal of Engineering \& Technology, $7(4.38)(2018) 551-555$
International Journal of Engineering \& Technology
SPC
Website: www.sciencepubco.com/index.php/IJET
Research paper

\title{
The Role of Animated Characters in the Socialization of Children in the Russian Federation
}

\author{
Dina Kabdullinovna Tanatova ${ }^{1 *}$, Ivan Vladimirovich Korolev ${ }^{1}$, Marina Vladimirovna Nevskaya ${ }^{1}$, \\ Liliya Rafaelevna Tairova ${ }^{1}$ \\ ${ }^{1}$ Russian State Social University, Wilhelm Pieck street, 4, build.1, Moscow, 129226, Russia \\ *Corresponding author E-mail: tanatova.d.k@bk.ru
}

\begin{abstract}
The studies of animated characters as a factor of socialization have virtually no theoretical or empirical interpretation in the Russian sociology. At the same time, cartoons have a huge potential for development and successful socialization of children. It is a well-known fact that animated films are widely used in pedagogy, psychology, and within the family circle. The public especially favors cartoons produced during the Soviet period, but gradually they become a thing of the past. This process is mainly due to the fact that visually and technologically they are inferior to modern cartoons and thus lose their appeal.

As a result of the availability of the Internet and Smart TV, the number of young users watching videos and TV broadcasts has risen significantly. The leaders of ratings in terms of views and popularity are cartoons made in the USA, which reflect the values and characteristics of Western society.

However, modern animated films boast a wide range of genres, plots, and characters created with the help of new technologies. Their pedagogical, cultural, and development potential is impressive, and their role in the socialization of children is still significant.
\end{abstract}

Keywords: animated characters, animated films, socialization, Soviet cartoon, foreign animation.

\section{Introduction}

As agents of socialization, family and school are ceasing to be the only media communicating socio-cultural capital: now they are sharing their functions of upbringing and developing a child's identity with TV and the Internet.

Animated films are an important institutional mechanism for socialization of children. In spite of the conditional and fictional nature of animated images and the entertainment function of cartoons, they convey an axiological message. An animation artist creates not only the appearance of the character, the background and decorations of the cartoon, but also endows it with internal content expressed in the views, beliefs, values, and behavior patterns of the animated characters. Distinctive features of their inner world are reflected in their actions, speech, behaviors, and unity of form and content. Therefore, an animated character is a carrier and transmitter of a particular value system which to a certain extent affects spiritual and moral development of a child and the process of their socialization [1]. Animated characters and the content of animated films are intended to form standards of behavior, sets of values, ethical and moral attitudes absorbed by children.

Modern animation involves a diversity of genres, artistic ideas, figurative and stylistic forms, and technical experiments. The great variety of types and forms of animated films in Russia is tightly related to the development of socioeconomic and technical processes in this country [2]. Until the 1980s, the animation industry in the USSR had been represented by Soyuzmultfilm studio and other companies from the Soviet bloc countries. After the breakup of the Soviet Union and transition to market economy, a few processes which influenced the development of animation took place. Firstly, when Russia opened its borders with the outer world, for- eign cartoons competing with the Russian animated films flooded the country. Secondly, a vast number of commercial projects were launched; in line with the market-economy principles, they were oriented at quantity and profit rather than quality and content, which leave much to be desired. Thirdly, the development of modern technologies has simplified the process of creating cartoons, which made it possible to organize their mass production. As a result, many cartoons do not perform their cognitive and pedagogical function and become only a leisure-time activity. Experts claim that some modern cartoons adversely affect the psyche and behavior of teenagers since they contain scenes of violence, aggression, and obscene language [3][4][5].

The issue of the impact that cartoons and animated characters, in particular, have on the socialization of children is discussed within the academic community and offers multiple opportunities for scientific research. For example, educators treat animation as a specific teaching method, psychologists view it as a mechanism of influence on the formation of a child's personality and psyche [6]; in the legal sphere, there are discussions which lead to prosecution of certain channels and cartoons they broadcast. Animated films have become an object of social control. For instance, in 2010 a federal law no. 436 "On Protection of Children from Information Harmful to Their Health and Development" [7] was adopted in Russia. It restricts the viewing of certain cartoons, which, according to experts, adversely affect the development of a child.

The issue of the impact that cartoons have on socialization of children has several aspects. Firstly, the traditional socialization institutions have largely lost their role. Increasingly long hours parents spend at work lead to the fact that children even from well-to-do families are left unattended and lack communication and control of their parents. Parents delegate responsibility for the upbringing of their children to other institutions: education and development 
centers, schools, babysitters, TV, etc. The pedagogical potential of school education is declining as a result of changes introduced into the school education implying that the priority task for schools is education rather than upbringing.

Secondly, the popularity of the Internet is still growing, children watch most cartoons online and are inspired by animated characters. Watching cartoons is one of the main leisure activities for children. Cartoons are available for everybody and sometimes substitute communication with adults, they help children to escape from problems, relax and have fun [8].

Thirdly, further globalization and development of the Internet, as well as the expansion of international ties and contacts, result in the emergence of various foreign cartoons in the communicative space, the content of which is very different and sometimes negative. For example, some western cartoons suggest a new ideal of a modern person: it is an independent strong-minded active individualist who succeeds in everything. In order to achieve the goal, he or she resorts to deceit, various cunning tricks and physical force. Their opponent is proclaimed a loser and made fun of. As a rule, characters of western animated films are very colorful, bright, and at times even provocative. They use their looks as an instrument for achieving their goals. Such cartoons promote western values and individualistic mindset different from the ideas typical for the Soviet cartoons, which reflect realistic view of the world and convey commitment to spiritual and ethical ideals and values adopted by the Russian society. Consequently, a modern teenager gets disoriented, since the continuity of inheriting social values is upset [9].

In the fourth place, there are some animated films intended for adults. The content of such films opens "the world of a grown-up person" in its full diversity to a teenager [10]. On the one hand, it allows teenagers to get to know the real world, but on the other hand, it has a negative effect, since teenagers are not yet ready for critical perception and analysis of the received information. The problem is made worse by the fact that nowadays parents cannot control their children to the full extent. A lot of channels and the Internet offer access to such cartoons. In the context of general availability of these materials and lack of parents' control, there is a danger of negative impact of such animated films on children's socialization. The uncontrolled flow of anti-social immoral abusive information destabilizes the childhood stage of teenagers' socialization.

\section{Methods}

In accordance with theoretical and methodological principles and specific nature of the subject and scope of research, the methodological approach is based on the integrative research strategy. This approach suggests using quantitative, qualitative, and visual methodologies which complement each other.

The main function of the group questionnaire is monitoring aimed at finding social information, which later serves as the basis for developing topics for focus group interviews. For example, the results of the questionnaire confirmed the hypothesis that animated films are the priority choice when children watch videos.

The authors selected a semi-structured focus group interview as the main qualitative method of obtaining various multi-level primary sociological information.

Empirical scope of research: primary school-aged children (9-11 years old) studying in grades 3-5 in Obninsk (Moscow Region). Objective of study: to identify the specific aspects of the impact which different animated characters have on the socialization of children. Quota sample. Socio-demographic criteria have been selected as the main quotas: age, gender, student of grades $3-5$, namely schoolchildren aged $9-11$.

\section{Results}

Within the questionnaire-based survey, 300 children were interviewed: 171 girls (57\%) and 129 boys (43\%) aged from 9 to 11 .

Most children (62.3\%) prefer animated films to other video materials. They prefer watching cartoons on the Internet (54.7\%) using convenient gadgets rather than on TV (35.3\%), which has also been highlighted in other works [11][12].

Based on the survey the authors compiled a rating of the best cartoons according to present-day preteens (Table 1).

Table 1: The rating (TOP-11) of the best cartoons according to preteens (May 2018)

\begin{tabular}{|l|l|c|}
\hline Place & Name of the cartoon & $\begin{array}{c}\text { Percentage } \\
\text { of respondents } \\
\text { who have chosen } \\
\text { the cartoon (\%) }\end{array}$ \\
\hline 1st-2nd & Masha and the Bear (2009-present) & $10.7 \%$ \\
\hline 1st-2nd & Fixiki (2010 - present) & $10.7 \%$ \\
\hline 3rd & Kikoriki (2004 - present) & $7.7 \%$ \\
\hline 4th & Tom and Jerry (1940-2017) & $5.3 \%$ \\
\hline 5th & Cars (2006, 2011,2017) & $5.0 \%$ \\
\hline 6th & SpongeBob SquarePants $(1999-2016)$ & $4.7 \%$ \\
\hline 7 th & Gravity Falls $(2012-2015)$ & $4.3 \%$ \\
\hline 8th & Scooby-Doo (1969-2010) & $3.3 \%$ \\
\hline 9th & Big Hero 6 & $2.7 \%$ \\
\hline 10th-11th & The Lion King $(1994,2002,2004)$ & $2.3 \%$ \\
\hline 10th-11th & Madagascar $(2005,2008,2012)$ & $2.3 \%$ \\
\hline
\end{tabular}

It should be noted that all cartoons, which have been chosen as favorite ones, have more than one part. It can be an animated series or a full-length animated film continued in the second and third parts (Big Hero 6 is an exception). Many of these series continue to be filmed up to now encouraging even higher interest in the new series.

Children named three main factors influencing their choice of favorite cartoons: if they like the characters and their behavior $27.7 \%$, if they find the cartoon funny and amusing $-25.3 \%$ (which proves the entertainment orientation of cartoons), and if they find the cartoon interesting $-22.7 \%$. It should be added that the plot of the cartoon plays a huge role in this distribution $(22.7 \%$ - interesting, $12.3 \%$ - educational, $11.3 \%$ - adventurous). The rating of favorite Soviet cartoons is represented in Table 2.

Table 2: The rating of favorite Soviet cartoons

\begin{tabular}{|l|c|}
\hline Name of the cartoon & $\begin{array}{c}\text { Percentage of respondents who have chosen } \\
\text { the cartoon (\%) }\end{array}$ \\
\hline Cinderella & $29.40 \%$ \\
\hline $\begin{array}{l}\text { The Adventures of Dun- } \\
\text { no } \\
\text { and his Friends }\end{array}$ & $26.90 \%$ \\
\hline The Kitten Named Woof & $26.90 \%$ \\
\hline The Snow Queen & $26.50 \%$ \\
\hline Leopold the Cat & $26.20 \%$ \\
\hline $\begin{array}{l}\text { Cheburashka and Gena } \\
\text { the Crocodile }\end{array}$ & $25.10 \%$ \\
\hline Well, Just You Wait! & $24.70 \%$ \\
\hline $\begin{array}{l}\text { The Bremen Town Mu- } \\
\text { sicians }\end{array}$ & $24.40 \%$ \\
\hline Mowgli & $24.00 \%$ \\
\hline $\begin{array}{l}\text { The Adventures of Bu- } \\
\text { ratino }\end{array}$ & $23.70 \%$ \\
\hline Prostokvashino & $22.60 \%$ \\
\hline
\end{tabular}

A conclusion can be made that, on the whole, Soviet cartoons are recognizable and popular with the Russian children.

The main features of animated characters, which modern children find appealing, are personality of the character, their actions, and distinguishing features. However, many children love cartoons just because they are amusing; consequently, their favor funny characters. A vivid example of such preferences is Masha from the animated series "Masha and the Bear": she does not possess any specific features or unusual appearance. Modern children find her 
personality and actions amusing, which is the reason for her leading position in the rating of characters (Table 3 ).

Table 3: The rating (TOP-10) of the best animated characters according to preteens (May 2018)

\begin{tabular}{|l|l|c|}
\hline Place & \multicolumn{1}{|c|}{ Name of the character } & $\begin{array}{c}\text { Percentage of respondents who } \\
\text { have chosen the character (\%) }\end{array}$ \\
\hline 1st & $\begin{array}{l}\text { Masha from the animated } \\
\text { series } \\
\text { "Masha and the Bear" }\end{array}$ & $10.3 \%$ \\
\hline 2nd & $\begin{array}{l}\text { Zero from the animated series } \\
\text { "Fixiki" }\end{array}$ & $6.7 \%$ \\
\hline 3rd & $\begin{array}{l}\text { Dipper from the animated } \\
\text { series } \\
\text { "Gravity Falls" }\end{array}$ & $6.0 \%$ \\
\hline 4th & Spider-Man & $4.7 \%$ \\
\hline $\begin{array}{l}\text { 5th- } \\
\text { 6th }\end{array}$ & Rapunzel & $4.0 \%$ \\
\hline $\begin{array}{l}\text { 5th- } \\
\text { 6th }\end{array}$ & SpongeBob & $4.0 \%$ \\
\hline $\begin{array}{l}\text { 7th- } \\
\text { 8th }\end{array}$ & $\begin{array}{l}\text { Jerry from the animated series } \\
\text { "Tom and Jerry" }\end{array}$ \\
\hline $\begin{array}{l}\text { 7th- } \\
\text { 8th }\end{array}$ & $\begin{array}{l}\text { Hiro from the full-length } \\
\text { animated film "Big Hero 6" }\end{array}$ & $2.3 \%$ \\
\hline
\end{tabular}

In the course of focus group interviews, the question "Which characters would you like to be similar to?" allowed the authors to identify the values and personality features important for teenagers and the characters they would like to model themselves on in their life and behavior. When asked to describe and evaluate cartoons, the respondents named the following main features: characters' appearance and actions, plot, and soundtrack. Based on these criteria they determined their most and least favorite cartoons. According to the theoretical approach used in this research, these components are the main elements of a cartoon as a communication framework. They convey the crucial ideological, aesthetic, and axiological message and can have a different impact on children's socialization, their social and psychological state and behavior. As it was mentioned earlier, these components are characters' appearance and actions, plot, and soundtrack.

In their responses teenagers identify several distinctive groups of cartoons: 1) Soviet cartoons which can be classified as the second type; 2) modern cartoons which can be classified as the third type, and 3 ) modern cartoons.

The majority of Soviet cartoons were made with the help of traditional animation techniques - these are mainly hand-drawn cartoons, which is why the images of animated characters are full of harmony and aesthetics. A vivid example is the cartoon "The Snow Queen" (1957): it creates a tasteful art mindset, while flowing lines, soft warm colors, and well-balanced images have a positive impact on the children's psyche and help them to develop a sense of beauty.

The Soviet cartoons are usually marked by high production quality since each cartoon was made exclusively and there was no flow production. They were created with due account for developmental psychology and physiology. In the Soviet times, there was a special editorial office dealing with children's TV and driven by humanistic approach to broadcasting aimed this age group [13]

The Soviet animation reflects the view of the world, which is normal for a child [14]. It is basically Orthodox because, according to this framework, evil is not eternal, while good is. As a rule, in this kind view of the world, there is a villain who can be easily redeemed. It turns out that the villain has been so malicious because he or she did not have any friends, nobody loved or sympathized with him or her. It is very important that in the Soviet cartoons the villain was pictured humorously, which balanced his or her ill nature. Soviet cartoons set correct behavior patterns: how to make friends, become a good companion, help others. The characters are easy to understand, possess clear personalities and show corresponding behavior. Surely, not all Soviet cartoons can be definitely classified as the second type, since there are some cartoons showing behavior patterns which are different from the gen- erally recognized norms (for example, the cartoon "Well, Just You Wait!" where the wolf smokes).

Soviet cartoons form a positive mindset and set the right direction for development among teenagers [14]. Evaluative remarks given by a respondent who watches only Soviet cartoons can be cited as an example supporting this view. He is indifferent to modern animation and calls it "stupid". The respondent prefers Soviet cartoons because they are insightful: "I adore Soviet cartoons, they always teach you something good..." (Serezha, 5th grade, 12 years old).

The animated character Doono is a role model for him, Serezha says, "He is very intelligent and well-mannered." Intelligence and knowledge are the main priorities in this respondent's value system. In his free time, he reads books, watches programs about science and animals, at school he gets excellent marks. "I'd like to be as clever and inventive..." So, the image of Doono shows the behavior patterns desirable for the respondent, supporting his focus on education and studies.

Another respondent, Polina, likes music cartoons best (e.g., "The Music Box"). According to her, the advantage of the Soviet cartoons is that "the voice work is very good, there are lots of songs, and in the modern ones there's nothing similar..." (Polina, 5th grade, 11 years old). The soundtrack to Soviet cartoons shapes her ear for music and encourages her interest in this sphere to grow even further.

Therefore, Soviet cartoons have a positive influence on children's socialization by creating an image of a spiritual person with high moral values.

As for the modern animation, the public opinion holds that it adversely affects children's socialization, behavior, and psychological state. However, modern cartoons are represented by a wide range of genres, unique plots and ideas, as well as stylistic forms created with the help of new technologies.

The foreign animation is heterogeneous [15], so it is impossible to assess its impact on the socialization of children in a precise way. Among the huge diversity of animated films, one can find cartoons of any type: the first, second, third, or fourth.

For example, let us consider the animated images of superheroes chosen by the respondents as role models. Images of superheroes differ in various cartoons. As a rule, a superhero character forms the value paradigm of a superstrong, successful and "cool" person who opposes the evil forces, helps and protects the weak.

"I'd like to be Spider-Man. It is so extreme, at any moment there's web, the next moment there's something else, I want to fight criminals - what a cool hero!" (Kirill, 4th grade, 10 years old)

A number of respondents think that Spider-Man is the most successful superhero and want to copy his behavior. They adhere to the principle that "a man should be a man". Independence, fairness, success, and general recognition are very important in their value system, which corresponds to the values of their role model.

Identification with this superhero among respondents can lead to their evolvement into successful, brave, and kind defenders of their families, homes, and motherlands.

However, some superhero cartoons are connected with rage and aggression, contain scenes of violence and contribute to behavior patterns, which imply that the use of force is a solution to any problem. Evidence provided by psychologists suggests that frequent viewing of such content has an impact on the psyche and behavior of a child: it increases their irritability, excitability, and aggressiveness. One of such animated series is "Deadpool". The main character is an anti-hero: he is a killer whose main features are physical strength, "coolness", and black humor. Deadpool demonstrates anti-social behavior patterns, he is violent and immoral.

Kirill, 4th grade, 10 years old: "I was watching Batman vs Deadpool, so he says, "I can show you I'm immortal, bang, shot himself in the head, fell down and got up - see, I'm alive again."

Moderator: "So that's cool?"

Kirill: "Well, yeaaah!" 
Anton, 4th grade, 10 years old: "And then he was blown up by a shell, and he said, "Get me a pizza too." (laughing)

Observation showed that the real-life behavior of a teenager who identifies with this character corresponds with the behavior pattern of this role model. He is aggressive, fights with other children, and is prone to outbursts of rage and anger.

One of the blocks of the focus group interviews was devoted to a comparison between two cartoons: a Soviet one and a foreign one. Their plots are pretty much the same, but their artistic presentation is different. The authors have chosen the following cartoons as objects of comparison: "The Simpsons" vs "Barboskiny. These cartoons will be used as examples in order to describe their distinctive features with the use of the developed theoretical model. Besides, their place in the research continuum will be determined, depending on their axiological, ideological, and aesthetic orientation.

"The Simpsons" and "Barboskiny" are modern cartoons centered around family life.

"The Simpsons" is an American animated series, which has been running for over 25 years. As it was mentioned earlier, it falls into the first type of cartoons and is forbidden on the Russian television for viewing by children. Nevertheless, in each focus group, there were respondents who watch this cartoon and think that it is "funny", "amusing", "about adventures". Not all children realize the negative impact of the cartoon; many of them find it interesting.

However, the authors have found out that most respondents think that "The Simpsons" is not meant for children. According to the interviewees, tough relationships among characters, obscene language, low-quality drawing, and strange characters have a negative influence on personality development.

Katya, 5th grade, 12 years old: "The Simpsons" make people stupid." Nadya, 5th grade, 11 years old: "Yes, they grow stupid! My brother watches this series, and he's got a D in Maths!" (exasperated).

"Barboskiny" (2011-2012) is a Russian animated series for children. According to its axiological content, it can be classified as the second type, since it promotes family, moral, and spiritual values. This series has a positive influence on the value system of teenagers.

In spite of that, the respondents remarked that the actions of the characters are not always reasonable, the plot is very simple, and the message is too plain to see, so some respondents consider this cartoon "too childish".

"I don't like "Barboskiny" because they are childish and act a bit stupid. Not like normal people. Some kind of bans, just nonsense..." (Sasha, 5th grade, 12 years old).

\section{Discussion}

In the 1970s and 1980s, the state television in the USSR was undergoing a stage of active development: the number of news channels was gradually growing along with the number of programs, films, and cartoons for children. Animation production was a part of the Soviet ideology; accordingly, the main goal of the Soviet moviemaking was the spiritual and moral development of a person. Plots of films and cartoons were humanistic, kind, and relevant to the age and level of children's development [16].

Starting from the 1990s, the situation changed dramatically. Television was commercialized. On the one hand, there were some positive changes: network channels for children appeared, diversity of program genres and types increased [17]. On the other hand, a few negative trends also manifested themselves. They were connected with deterioration in quality and volume of children's broadcasting, destruction of the national culture, increase in the imports of foreign cartoons. Children's film industry has become a part of the market where the main criterion of success is economic performance. Modern film products should, in their turn, generate profit. In order to attract viewers, the product should be absolutely astonishing. The picture should be colorful, pretty, and dynamic. Technological development and cutting-edge solutions in the area of human perception allow filmmakers to achieve these goals [6]. The leaders of ratings in terms of views and popularity are cartoons made in the USA, which reflect the characteristics of the American society. Western values are the main focus of these cartoons: individualism, competition, striving for leadership, success, and material welfare.

Favorite Soviet cartoons are gradually leaving the TV screens [18] They are visually and technologically inferior to the modern cartoons and thus lose their appeal. Modern animated films are more colorful, bright, and gripping.

In the meantime, cartoons can be called tools of mass influence aimed primarily at children. Socially meaningful information is represented by images of characters and moving pictures, which form a dynamic system, making animated films extremely appealing to young audience. The viewers are influenced through visual and audio-visual communication channels, which facilitates easy and fast absorption of information.

Compared with adults, children perceive cartoons in a substantially different way. Adults rely on rational thinking, which is why they do not trust cartoons as much as children do. While watching an animated film from the perspective of their life experience, adults and children build different models of reality. "The younger the viewer is, the more closely he or she observes the main character, their motives and life values without fully realizing it. At a young age, the issues of reasons for existence, main values and motives, behavior patterns in different situations are of utmost importance." [19].

Different perception is connected with the fact that a cartoon is not only a form of entertainment for a child but also a source of knowledge.

It should be noted that the volume of information (message) received by a teenager is never equal to the meaning attributed to the message by the communicator. On the one hand, the volume of the received information is less than that sent by the communicator because the recipient never fully perceives the given information. On the other hand, it is bigger because in the recipient's perception of the information provided by the communicator interacts with the data he or she had already possessed before reading the book or watching the film. The multifaceted nature of meaning is incorporated in the perception of information rather than in the initial message. It is determined by the communicative and artistic approach and, in essence, by the values behind it.

Animated characters influence children due to a number of socialization mechanisms [20].

1. Informing - raising the awareness of the world around us, establishing the primary ideas of good and evil, positive and negative role models.

2. Identification - absorption of social attitudes and values by a child through comparison of oneself to cartoon characters.

3. Interiorization (internalization) - accepting the social conventions, values, evaluations, and behavior patterns of animated characters as one's own beliefs.

4. Reproduction - voluntary or involuntary following the role models and behavior patterns demonstrated by animated characters.

5. Imitation - copying the actions of animated characters and their image in general.

6. Acting out film plots - role-playing standard everyday life situations children face in the course of communication with other members of society. They contain social norms, rules, gender roles, values, and behavior patterns. Later children act out these plots many times, solidifying the patterns of conduct in different situations.

7. Reflection - internal dialogue in the course of which a person considers, evaluates, accepts or rejects certain norms or values.

8. Imprinting - engraving the distinctive features of animated characters on the subconscious level. For example, the image of 
Prince Charming can affect the future relationships of a girl with men.

\section{Conclusion}

Each cartoon and animated character convey their own axiological, ideological, and aesthetic message, which can have different impact on the socialization of children. Some of them significantly influence children's behavior, communication, values, mood, and perception, whereas others cause aggression, indifference, loneliness, and irritability.

On the whole, the following aspects of impact, which animated characters have on the socialization of children, can be identified:

1. Children follow the role models and behavior patterns demonstrated by animated characters both voluntarily and involuntarily.

2. Children accept the social conventions, values, evaluations, and behavior patterns of animated characters as their own beliefs.

3. Children absorb social attitudes and values through comparison of themselves to cartoon characters.

Cartoons raise children's awareness of the world around us, establish the primary ideas of good and evil, positive and negative role models.

\section{References}

[1] Golovanova NF. Sotsializatsiya i vospitanie rebenka [Socialization and upbringing of a child]. St. Petersburg, Rech, (2004), $272 \mathrm{p}$.

[2] Asenin SE, Mir multfilma [The world of cartoon]. Moscow, Iskusstvo, (1986), 308 p.

[3] Medvedeva IYa, Shishova TL, Raznotsvetnye belye vorony [Multicolored black sheep]. Moscow, Semya i shkola, (1996), 268 p.

[4] Markova NE, Kultrinterventsiya [Cultural intervention]. Moscow, Omega, (2002), 90 p.

[5] Ermizina EV, Multfilm - deti: ot konteksta k ponimaniyu [Cartoon and kids - from context to understanding]. Mir psikhologii, 1 , (2010), pp. 51-58.

[6] Suvorova NV, Multiplikatsiya kak sposob vliyaniya na formirovanie sotsiokulturnoi identichnosti rebenka [Animation as a means of formation of a child's socio-cultural identity]. Molodoi uchenyi, 8, (2014), pp. 740-742.

[7] Federal law of the Russian Federation no. 436 "On Protection of Children from Information Harmful to Their Health and Development" of 21 December (2010). Corpus of Legislative Acts of the Russian Federation. 03.01.2011, No. 1, Article 48 amended and revised as of 10.08.2018.

[8] Popov EA, Animatsionnoe proizvedenie: tipologiya i evolyutsiya obraznykh sredstv [Animated video: typology and evolution of imagery]: Ph.D. thesis in Art Criticism (17.00.09). St. Petersburg, (2011), $198 \mathrm{p}$.

[9] Piaget J, Suzhdenie $i$ rassuzhdenie rebenka [Judgement and Reasoning in the Child]. St. Petersburg, Soyuz, (1997), 288 p.

[10] Malysheva A, Chto takoe multiplikatsiya? Tekhnologii sozdaniya multfilmov [What is animation? Technologies of creating cartoons]. Online-portal FB.ru, (2016), available online: http://fb.ru/article/ 235833/chto-takoe-multiplikatsiya-tehnologii-sozdaniyamultfilmov, last visit: 01.09.2018.

[11] Tanatova DK, Tairova LR, Mobilnye gadzhety kak faktor temporalnosti povsednevnoi zhizni rossiiskogo naseleniya [Mobile gadgets as a temporality factor in the everyday life of the population of Russia]. Sotsialnaya politika i sotsiologiya, Vol. 2, No. 4-1 (105), (2014), pp. 209-217.

[12] Tanatova DK, Sotsialnye neravenstva i dinamika izmenenii v sovremennom mire [Social inequality and the dynamics of change in the modern world]. Sotsialnaya politika i sotsiologiya, Vol. 2, No. 4-1 (105), (2014), pp. 201-208.

[13] Nemova OA, Burukhina AF, Multiplikatsionnye filmy kak sredstvo formirovaniya semeinykh dukhovno-nravstvennykh tsennostei [Animated films as a means of shaping family spiritual and moral values]. Vestnik MSU, 1, (2014), pp. 152-173.

[14] Vygotsky LS, Psikhologiya iskusstva [The Psychology of art]. Rostov-on-Don, Feniks, (1998), $480 \mathrm{p}$

[15] Krivulya NG, Evolyutsiya khudozhestvennykh modelei v protsesse razvitiya mirovykh animatografii [The evolution of artistic models in the course of world animation development]: Art Criticism doctoral thesis (17.00.03). Moscow, (2009), $198 \mathrm{p}$.

[16] Laletina AF, Kulturoobrazuyushchee znachenie multiplikatsii [The culture-forming function of animation]. Lingvokulturologiya, 3, (2009), pp. 142-147.

[17] Tsymbalenko SB, Sharikov AV, Shcheglova SN, Informatsionnoe prostranstvo rossiiskogo podrostka $v$ postsovetskii period: (sotsiologicheskii analiz) [Information space of a Russian teenager in the post-Soviet period (sociological analysis)]. Moscow, NII shkolnykh tekhnologii, (2006), $128 \mathrm{p}$.

[18] Kapkov S, Sovetskie multfilmy ukhodyat v proshloe [Soviet cartoons are becoming a thing of the past]. FOM-MEDIA, (2011), available online: https://fom.ru/blogs/10098, last visit: 30.07 .2018 .

[19] Iosifyan SA, Petrovskii VA, Kinematograf: detskii i podrostkovyi, zritel [Filmmaking: aimed at children and teenagers; the audience]. Sotsiologicheskie issledovaniya, 3, (1995), pp. 83-88.

[20] Bogdanova OA, Mediapedagogika kak neobkhodimaya sostavlyayushchaya sotsializatsii rebenka $\mathrm{v}$ informatsionnom obshchestve [Media pedagogy as a necessary component of a child's socialization in the information society]. Vestnik Moskovskogo gorodskogo pedagogicheskogo universiteta, Series: Informatics and informatization of education, 1, (2013), pp: 106-111. 